\title{
Okul Öncesi Eğitimi Dergisine bir bakış: Tarihsel trendler ve gelecek vizyonu
}

\author{
Journal of Early Childhood Education: Historical trends and future \\ vision \\ Nesrin Iş1koğlu${ }^{1}$, Serap Erdoğan ${ }^{2}$, Zeynep Ceren Şimşek ${ }^{3}$, Özge Akgün ${ }^{4}$ \\ Makale Geçmişi \\ Geliş : 11 Mart 2021 \\ Düzeltme : 30 Temmuz 2021 \\ Kabul : 3 Ağustos 2021

\section{Makale Türü} \\ Arasstrma Makalesi \\ Öz: Bu çalışma, Türkiye'de Erken Çocukluk Eğitimini Geliştirme Derneği tarafindan yayımlanan Erken \\ Çocukluk Eğitimi Dergisi'nde 1968-1994 yılları arasında yayınlanan makaleleri incelemeyi \\ amaçlamaktadır. Nitel araştırma yöntemi ile yapılan çalışmada beş aşamalı bir belge analizi süreci \\ kullanılmıştır. Ayrıca dergide1968-1994 yılları arasında yayınlanmış makaleleri bulunan iki gönüllü \\ akademisyen ile yarı yapılandırılmış görüşmeler yapılmıştır. Bulgular, yayınlanan makalelerin çoğunun üç \\ ile altı yaş arasındaki çocukları hedefleyen derleme makaleler olduğunu, sıfır ile iki yaş arasındaki \\ çocuklarla ilgili makale sayısının çok daha düşük olduğunu göstermektedir. Makaleler derinlemesine \\ incelendiğinde çocuk gelişimi ve eğitimine sıklıkla yer verildiği, ebeveyn katılımı ve çocuk sağlı̆̆ ve \\ bakımı konularının ise artarak makalelerde yer aldığını söylemek mümkündür. Son olarak, erken \\ çocukluk eğitiminin önemini, sorunlarını ve gelecek vizyonunu ortaya koyan makaleler, amaç / öneriler \\ teması altında tartışılmıştır. \\ Anahtar Kelimeler: Erken çocukluk eğitimi, Erken çocukluk çalışmaları, Okul Öncesi Eğitimi dergisi \\ Abstract: This study aims to examine the articles situated between 1968-1994 in the Journal of Early \\ Childhood Education which was published by the Association for the Development of Early Childhood \\ Education in Turkey. A five-stage document analysis process was used in the study conducted with the \\ qualitative research method. Additionally, semi-structured interviews were conducted with two \\ volunteered academicians who had a published article in the journal between 1968-1994. The findings \\ show that while there are many review articles targeting children between the ages of three and six, the \\ number of articles on children aged between zero and two is much lower. When the main topics of the \\ articles are examined closely, it is possible to explain that child development and education are common \\ topics in the published articles, and then parental involvement and child health and care are other main \\ topics. Lastly, the articles which were revealing the importance, problems, and future vision of early \\ childhood education were discussed under the theme of purpose/suggestions. \\ Keywords: Early childhood education, Early childhood studies, Journal of Early Childhood Education
}

DOI: $10.24130 /$ eccdjecs.1967202152372

\footnotetext{
Başlıca Yazar:

${ }^{1}$ Pamukkale Üniversitesi, Eğitim Fakültesi, Temel Eğitim Bölümü, Okul Öncesi Eğitimi Anabilim Dalı, nisikoglu@pau.edu.tr, ORCID: http://orcid.org/0000-0001-7010-302X

${ }^{2}$ Anadolu Üniversitesi, Eğitim Fakültesi, Temel Eğitim Bölümü, Okul Öncesi Eğitimi Anabilim Dalı, serape@anadolu.edu.tr, ORCID: http://orcid.org/0000-0001-6149-4460

${ }^{3}$ Pamukkale Üniversitesi, Eğitim Fakültesi, Temel Eğitim Bölümü, Okul Öncesi Eğitimi Anabilim Dalı, cyesilyurt@pau.edu.tr, ORCID: http://orcid.org/0000-0002-6622-7289

${ }^{4}$ Anadolu Üniversitesi, Eğitim Fakültesi, Temel Eğitim Bölümü, Okul Öncesi Eğitimi Anabilim Dalı, ozgeakgun@ anadolu.edu.tr, ORCID: http://orcid.org/0000-0003-4799-237X
} 


\section{SUMMARY}

\section{Introduction}

This study aims to examine the articles published between 1968-1994 in the Journal of Early Childhood Education which was published by the Association for the Development of Early Childhood Education in Turkey. Current research reveals that early childhood is a critical period in which fundamental skills and habits that will shape the basis of human development are acquired (Rebello Britto, Engle, \& Super, 2013; Sylva, Melhuish, Sammons, Siraj-Blatchford, \& Taggart, 2010). It is well recognized that early childhood education plays a major role in young children's learning, increasing academic success, and building a healthy society. However, the scientific articles published in the field of early childhood education in Turkey had focused on similar issues and faced difficulties to reach large audiences(Ayylldız ve Albayrak, 2020; Can ve K1lıç, 2019; Doma \&Toran, 2020; Öztürk, Kaya ve Durmaz, 2015; Sabanc1, Altun ve Uçar Altun, 2018; Tuzcu, 2019). For this reason, analyzing early childhood education researches throughout the historical process will serve as an important guide to the current research studies and this study will draw attention to the development of early education in Turkey, its policies, and its sustainability. Therefore, this study will analyze the articles published in the Journal of Early Childhood Education between 1968-1994.

\section{Method}

A historical case study design, one of the qualitative research models, was used to examine the articles published between 1968-1994 in the Journal of Early Childhood Education. The main feature of historical case studies is that they describe the case/organization/phenomenon holistically in a certain period and present a historical perspective while doing this (Aytaçl1, 2012; Merriam, 2013). To collect the data, the "article evaluation form" was created by the researchers, and all published articles in the journal were coded by two researchers. Additionally, semi-structured interviews were conducted with two volunteered academicians who had a published article in the journal between 1968- 1994. For data analysis, a five-stage document analysis process, which included access to documents, verification of authenticity, reading, and understanding, analyzing, and interpreting was used.

\section{Results}

The findings of this study were discussed within the framework of two main themes as technical features and content features of the articles. The theme of content features was presented in three sub-themes as age groups, subject areas, and purpose/suggestions that the articles dealt with. Examination of technical features of the articles published in the Journal of Early Childhood Education indicated that of 283 published articles $85 \%$ of them were review studies, $12.7 \%$ were translations, and $2.12 \%$ were research studies.

In terms of the content of the articles it also is noteworthy to mention that most of the published articles have targeted children aged between three to six and the number of articles related to the children between zero to two was remained very low. Again, after a close examination of articles in terms of their main subjects it is possible to disclose that child development and education were the common subjects across the published articles, and then parent involvement and child health, and care issues were the other major 
subjects. Lastly, the published articles revealing the importance, problems, and future vision of early childhood education were examined under the theme of purpose/suggestions. The results of this document analysis were also confirmed by academician interviews.

\section{Conclusion and Discussion}

This study concludes that the Journal of Early Childhood Education greatly supported the development of early childhood education in Turkey. Firstly, among the published articles the number of research studies is very limited. The fact that early childhood education was not structured academically in the 1968s when the journal first started its publication life, explains this situation. Secondly, articles in that period mainly focused on children aged 3-6. For this reason, the increase of academic publications targeting the education of children aged 0-3 will draw attention to the importance of early learning in society. Thirdly, during 50 years of publication, many articles in the journal focused on main subjects such as education, child development, and parenting. In this direction, it is recommended to include research examining technology, media, new educational models, program evaluation, experimental program development, religious and cultural effects into the literature. Fourthly, the main problems that the Early Childhood Education Journal focused on since its first appearance are still valid problems in the literature (Ayyıldız ve Albayrak, 2020; Can ve Kılıç, 2019; Öztürk, Kaya ve Durmaz, 2015; Sabanc1, Altun ve Uçar Altun, 2018; Tuzcu, 2019). Fifthly, the results emphasized that the audience that periodicals can reach is still limited and that those who read the research were again researchers. For this reason, it is recommended that the journals could publish summaries of scientific research results, which are concrete, short, understandable, free from academic jargon, and contain goals, results, and suggestions on the social media pages. Lastly, scientific journals can encourage the authors to translate and publish short summaries of important articles published in foreign languages. 


\section{GİRIŞ}

Okul öncesi eğitim, tarihin ilk dönemlerinden beri üzerinde düşünülen ancak 1900'lü ylllar itibariyle önemine ve gerekliliğine ilişkin uluslararası farkındalık oluşan bir eğitim sürecidir. İlk yılların çocuğun gelecek yaşamı üzerindeki etkisinin anlaşılmasıyla birlikte toplumlar kendi ihtiyaç, inanç ve beklentilerine yönelik çeşitli okul öncesi eğitim politikaları geliştirmişlerdir (Kamerman, 2006; Regan,1976; Schwartz,1997). Uluslararası literatür incelendiğinde okul öncesi eğitimin şekillenme sürecinin toplumlar arasında farkllılı gösterdiği görülmektedir. Ülkelerin gelişim düzeyi, hedef ve beklentileri, eğitim harcamaları ve diğer eğitim kademelerinde ulaşılan okullaşma oranları okul öncesi eğitimin gelişimine yön vermiştir. Bu sebeple okul öncesi eğitimin gelişimi tarihsel bağlamda incelenirken, toplumun içerisinde bulunduğu koşullar göz önünde bulundurularak analiz edilmesi önem taşımaktadır (Bennett,2008; Bertram ve Pascal, 2016; Penn,2011).

Türkiye'de okul öncesi eğitimin gelişimi tarihsel bağlamda incelendiğinde; Cumhuriyet öncesi dönemde de okul öncesi eğitim hizmeti sağlayan kurumların bulunduğu ve okul öncesi eğitim ile ilgili ilk somut adımların II. Meşrutiyet döneminde atıldığı görülmektedir. 1909 yllında Selanik’te Ravza-i Sıbyan mektebi içerisinde bir okul öncesi sınıfı açılmış (Temizyürek ve Dinçer, 2014, s. 175), 1912-1913 yıllarında ise Resmî Ana Mekteplerinin açılmasıyla okul öncesi eğitim hizmetleri yaygınlaşmaya başlamıştır. 1914 yllında eğitim bütçesi içerisinde "Çocuk Bahçesi” olarak isimlendirilen okul öncesi eğitim kurumlarının açılması için de ödenek ayrılmış ve 1916 yılı sonlarına kadar İstanbul'da resmi okul öncesi eğitim kurumlarının sayısı 30'a ulaşmıştır (Güdek, 2012). 1930’lu yıllarda halkın okuryazar oranının artırılmasının üzerinde durulması sebebiyle okul öncesi eğitime verilen destek ikinci planda kalmış, 1960’lı yıllar itibariyle okul öncesi eğitimde okullaşma oranının artırılmasına ilişkin planlamalar yapılmış ancak bu sefer de bütçe sorunları ile karşı karşıya kalınmıştır (Akyüz, 1996; Çelik ve Gündoğdu, 2007; DPT, 1972; Gül, 2008). 1950’li y1llardan itibaren okul öncesi eğitimin yaygınlaştırılması ve geliştirilmesi için çeşitli adımlar atılmış, Türk eğitim politikalarına yön veren Millî Eğitim Şûraları ve Kalkınma Planlarında okul öncesi eğitime yer verilmiştir. Ancak planlamalar genel itibariyle okullaşma oranının artırılmasına yönelik yapılmış olup; kaynak eksikliği, okul öncesi eğitimin diğer eğitim kademelerine göre ikinci planda kalması gibi nedenlerle hedeflenen okullaşma oranlarına ulaşılamamıştır. Bunun yanı sıra; eğitim politikaları niceliksel artışa odaklanırken, mevcut okul öncesi eğitim kurumlarının nitelik sorunları ikinci planda kalmıştır. Sel (1974), Cumhuriyetin 50. yllına gelindiğinde okul öncesi eğitimin, Türk eğitim sisteminin ana sorunlarından biri olması rağmen hala çözülemediğini ifade etmiştir.

Okul öncesi eğitim meselesinin çözülememesi bilimsel araştırmalara olan gerekliliği ortaya koymuş, 1970’li yıllar itibariyle ülkemizde okul öncesi eğitim araştırmaları hız kazanmıştır. Bu durum çeşitli 
dergilerde okul öncesi eğitim alanında araştırmaların yayınlanmasına da ivme kazandırmıştır. 19601994 yılları aralığında okul öncesi eğitim alanında araştırmalar yayınlayan dergilere örnek olarak; Eğitim ve Bilim Dergisi, Ankara Üniversitesi Eğitim Bilimleri Fakültesi Dergisi, Hacettepe Üniversitesi Eğitim Fakültesi Dergisi ve Yaşadıkça Eğitim Dergisi gösterilebilir. Bu dergilerin 19681994 yılları aralığında yayınlanan sayıları incelendiğinde; Türkiye'de okul öncesi eğitimin gelişimi ve güncel durumu, farklı ülkelerde okul öncesi eğitim uygulamaları, okul öncesi eğitim kurumlarının işleyişi, okul öncesi öğretmenlerinin sorunları, okula uyum ve hazırbulunuşluk, çocuk gelişimi, teknoloji ve çocuk, özel gereksinimli çocuklar ve ebeveynlere yönelik araştırmalara yer verildiği görülmektedir. Ayrıca okul öncesi dönemde oyun, drama, yaratıcılık, müzik ve çocuk edebiyatı konularını içeren çalışmalara da rastlanmıştır. Bu araştırmalar okul öncesi eğitim politikalarına ve uygulamalarına da ciddi bir şekilde destek vermiştir. Okul öncesi eğitim araştırmalarının tarihsel süreç içerisinde analiz edilmesi günümüz araştırmalarına yol göstermekle birlikte Türkiye'de okul öncesi eğitimin gelişimini, uygulanan politikaları ve bu politikaların sürdürülebilirliğini gözler önüne serebilecektir.

Yurtiçinde okul öncesi eğitim araştırmalarının analiz edildiği çalışmalar incelendiğinde; drama, sosyal duygusal gelişim, fen eğitimi vb. belirli konulara yönelik yapılmış olan lisansüstü tezlerin (Ahi ve Kıldan, 2013; Altun, Şendil ve Şahin, 2011; Karaoğlu ve Çoban, 2019; Kaytez ve Durualp, 2014; Ogelman, 2014; Can-Yaşar ve Aral, 2011) ve yine belirli konu ve kavramlara yönelik araştırmaların sentezlendiği makalelerin (Bağcı ve İvrendi, 2016; Bakkaloğlu, Yılmaz, Könez ve Yalçın, 2018; Çiftçi ve Ersoy, 2019; Güneş, 2018; Yılmaz, Uyar ve Sığırtmaç, 2020; Yerliyurt ve Ersoy, 2020) incelendiği pek çok araştırmaya rastlanmaktadır. Ancak okul öncesi eğitim alanında yayın yapan dergilerin içerik analizinin yapıldığı çalışmaların sınırlı olduğu göze çarpmaktadır. Doma ve Toran (2020), 1986 yılında yayınlanmaya başlayan Yaşadıkça Eğitim Dergisinin içeriklerini erken çocukluk eğitimi bağlamında incelenmiştir. Yapılan bu araştırma okul öncesi eğitim alanında tarihsel süreç içerisinde odaklanılan konuları ortaya koymuş ve günümüzde hala önlemler alınması gereken konuların altını çizerek eğitim araştırmalarının tarihsel süreç içerisinde analiz edilmesinin önemini vurgulamıştır.

Türkiye Okul Öncesi Eğitimini Geliştirme Derneği tarafindan 1968-1994 y1lları aralığında yayınlanan Okul Öncesi Eğitim Dergisi, Türkiye'de erken çocukluk eğitimini kapsamlı bir şekilde ele alan ilk tematik dergidir. Türkiye Okul Öncesi Eğitimini Geliştirme Derneği, 1967 yllında kurulan ve 1972 yilından itibaren Erken Çocukluk Eğitimi Dünya Organizasyonunun Türkiye temsilciğini yürüten bir sivil toplum kuruluşudur. Okul Öncesi Eğitim Dergisinin amacı ise; okul öncesi eğitimine yönelik bilgi ve farkındalığı arttırmak, okul öncesi eğitimin sorunlarını, eğilimleri 
ve politikaları ortaya koymak ve öneriler geliştirmektir. Dergi müfredatı incelendiğinde; Türkiye'de okul öncesi eğitimin tarihsel gelişimi, okul öncesi eğitimin amac1 ve önemi, çeşitli ülkelerin okul öncesi eğitim programları, öğretmen yetiştirme sistemi, çocuk sağlığı ve gelişimi, özel gereksinimli çocukların eğitimi, anne-baba eğitimi vb. konulara yer verildiği görülmektedir. Dergi; okul öncesi eğitimin mevcut sorunlarını, eğilimleri, politikaları ve uygulamaları analiz etmenin yanı sıra okuyuculara çeşitli bakış açıları ve politika önerileri de sunmuştur.

Bu araştırma kapsamında incelenen Okul Öncesi Eğitim Dergisi; okul öncesi eğitimin sorunlarını, geliştirme ve yaygınlaştırmaya yönelik adımlarını, eğilimlerini ve politikalarını tarihsel süreç içerisinde değerlendirerek alan yazına katkı sağlamış bilimsel bir dergidir. Bu bağlamda okul öncesi eğitimin tarihsel süreç içerisinde analiz edilmesinin günümüze ve gelecek araştırmalara çeşitli bakış açıları sunabilmesi açısından önem taşıdığı düşünülmektedir.

Bu çalışmanın amacı okul öncesi eğitimi dergisinde yayınlanan makalelerin özelliklerinin tarihsel süreç içinde derinlemesine incelenmesidir. Bu amaç doğrultusunda aşağıdaki sorulara cevap aranmıştır:

1. 1968-1994’te yayınlanan makalelerin teknik ve içerik özellikleri nelerdir?

2. Okul öncesi eğitimi dergisinin yazarlarının yayınlara yönelik görüşleri ve önerileri nelerdir?

\section{YÖNTEM}

\section{Araştırmanın Modeli}

1968 ile 1994 yılları arasında Okul Öncesi Eğitimi Dergisinde yayınlanan makalelerin incelendiği bu araştırmada nitel araştırma desenlerden tarihsel durum araştırması kullanılııışır. Durum araştırması sınırları belirli bir sitemin derinlemesine betimlenmesi ve incelenmesidir (Merriam, 2013). Tarihsel durum araştırmalarının temel özelliği vakayı/organizasyonu/olguyu belli bir zaman aralığında bütüncül olarak betimlemesi ve bunu yaparken tarihsel bir bakış açısı sunmalarıdır (Aytaçlı, 2012; Merriam, 2013). Okul öncesi eğitimi dergisinin bir vaka olarak kabul edildiği bu araştırmada, dergide yer alan makaleler 1968 ile 1994 yılları arasındaki tarihsel süreci yansıtarak incelenmiştir.

\section{Verilerin Toplanmas1}

Araştırmanın verilerinin toplanmasında doküman analizi ve yarı yapılandırılmış görüşme teknikleri kullanılmıştır. Doküman analizi bir konu ya da duruma ilişkin yazılı belgelerin sistematik olarak 
toplanmas1 ve incelenmesini kapsar (Cresswell, 2017; Merriam, 2013; Wach, 2013). Genellikle doğrudan gözlem yapmanın olasılık dışı olduğu durum ve olguları incelemek için dokümanların/belgelerin toplanması araştırmacıya bağlam hakkında ayrıntılı bilgi oluşturma şansı sunarken; aynı zamanda da ek araştırma verileri de sağlayarak görünmeyeni ortaya çıkarma firsatı verir (Bowen, 2009). Bu araştırmada Okul Öncesi Eğitimi Geliştirme Derneği tarafindan tüm sayılarıyla kamuya açılan Okul Öncesi Eğitimi Dergisinin 1968-1994 yılları arasında yayınlanan 283 adet makalesinin tamamı analiz edilmiştir.

Ayrıca dokümanlardan elde edilen verileri desteklemek amacıyla 1968-1994 yılları arasında dergide yayını bulunan ve araştırmaya katılmayı kabul eden iki akademisyen ile yarı yapılandırılmış görüşmeler yapılmışır. Araştırmacılar tarafından oluşturulan görüşme soruları 4 alan uzmanı akademisyenin görüşüne sunulmuş ve önerilen değişikler yapıldıktan sonra görüşme sorularına son şekli verilmiştir. Yarı yapılandırılmış görüşmeler okul öncesi eğitimi dergisinin tarihi, içeriği, kapsamı ve alana etkisi, Türkiye'de okul öncesi eğitimle ilgili akademik yayınların niteliği ve sonuçlarını içeren 16 sorudan oluşmaktadır. Araştırmaya katılması için o dönemde dergide yayını olan beş akademisyen ile telefonla görüşülmüş, ancak yoğun olmaları, pandemi koşulları gibi çeşitli nedenlerle sadece iki akademisyen çalışmaya katılmayı kabul etmiştir. Katılımcı akademisyenlerden biri ile dijital ortamda çevrimiçi görüşme yapılmıştır. Bu kapsamda yapılan görüşme 60 dakika sürmüş ve katılımcının onayı alınarak kaydedilmiştir. Diğer akademisyen ise görüşme sorularına yazılı cevap vermeyi tercih etmiştir. Katılımcıların isimleri gizli tutularak akademisyen 1 ve akademisyen 2 olarak adlandırılmışlardır.

\section{Verilerin Analizi}

Toplanan dokümanların analizinde; belgelere ulaşma, orijinalliği teyit etme, okuma ve anlama, analiz etme ve yorumlamayı içeren beş aşamalı doküman analizi süreci kullanılmıştır (Forster, 2006). Bu kapsamda birinci aşamada 1968-1994 yılları arasında basılmış tüm makaleler derginin web sayfasından indirilerek kaydedilmiştir. İkinci aşamada dokümanların orijinalliği kontrol edilmiş ve üçüncü aşamada derginin bütün sayı/ciltleri ve içerisinde yer alan makaleler okunmuştur. Dördüncü aşamada ise araştırmacılar tarafindan makale değerlendirme formu oluşturulmuş ve tüm makaleler tekrar detaylı olarak okunarak bu forma kaydedilmiştir. Bu formda makalenin türü, içeriği, konuların odaklandığ yaş grubu ve makalelerin hedef kitlesi gibi makaleleri özetleyici bilgiler bulunmaktadır. Son aşamada, makale değerlendirme formunda yer alan tema ve kategorilere göre makaleleri özetleyen tablo ve grafikler hazırlanmış ve tema ile kategorileri betimleyen alıntılar saptanmıştır. Görüşme verileri yazıya dökülerek okunmuş ve tekrar okunmuştur. İki araştırmacı 
tarafından kodlanarak, doküman analizinde belirlenen temalar çerçevesinde alıntılar seçilerek doküman analizi verileri ile birlikte sunulmuştur.

\section{İnandırıcılık ve Aktarılabilirlik}

Çalışmanın inandırıcıllğını ve aktarılabilirliğini sağlamak için uzman görüşü, kodlayıcılar arası tutarlılık, ayrıntılı betimleme ve veri çeşitlemesi teknikleri kullanılmıştır. İlk olarak veri analizinde kullanılmak üzere geliştirilen makale değerlendirme formu; alanında uzman dört öğretim üyesine gönderilerek görüşleri alınmıştır. Uzman geribildirimleri doğrultusunda forma son şekli verilmiştir. Kodlayıcılar arası tutarlılı̆ı hesaplamak için dergi makalelerinin \%10’u iki araştırmacı tarafından kodlanmıştır. Kodlayıcılar arası tutarlılık, uzlaşma sayısı/uzlaşma sayısı+uzlaşmama sayısından oluşan toplam kodlara bölünerek hesaplanmış ve \%81 olarak bulunmuştur (Miles ve Huberman, 1994). Daha sonra kalan makaleler iki araştırmacı tarafindan ayrı ayrı kodlanmıştır. Araştırmada ortaya çıkan temaların ayrıntılı betimlenmesi için dergi makalelerinin özetleri ve temaları yansıtan bölümlerden doğrudan alıntılar yapılmıştır. Son olarak, dokuman analizinden elde ettiğimiz bulguları veri çeşitlemesi ile desteklemek için yarı yapılandırılmış görüşmeler dergide makalesi yayınlanan akademisyenlerle yapılmıştır.

\section{BULGULAR}

Okul öncesi eğitimin tarihsel trendlerini belirlemek amacıyla yapılan bu araştırmada elde edilen bulgular makalelerin teknik özellikleri ve içerik özellikleri olarak iki temel tema çerçevesinde ele alınmıştır. Teknik özellikler teması araştırmaların türlerine ve katılımcıların görüşlerine odaklanırken; içerik özellikleri teması makalelerin ele aldığı yaş grupları, konu alanları ve amaç/önerileri olarak üç alt tema çerçevesinde sunulmuştur.

\section{Makalelerin Teknik Özelliklerine İlişkin Bulgular}

Okul öncesi eğitimi dergisinde yayınlanan makalelerin teknik özellikleri tarihsel süreç içinde incelendiğinde yayınlanmış toplam 283 adet makalenin; \%85'inin derleme, \%12,7'sinin yabanc1 dilden çevirisi yapılmış derleme ve \%2.12'sinin araştırma makalesi türünde yayınlanmış eserler olduğu görülmektedir. Bugüne kadar toplam Yayınlanan makale türlerinin yıllara göre dağılımı Şekil 1'de gösterilmiştir. 


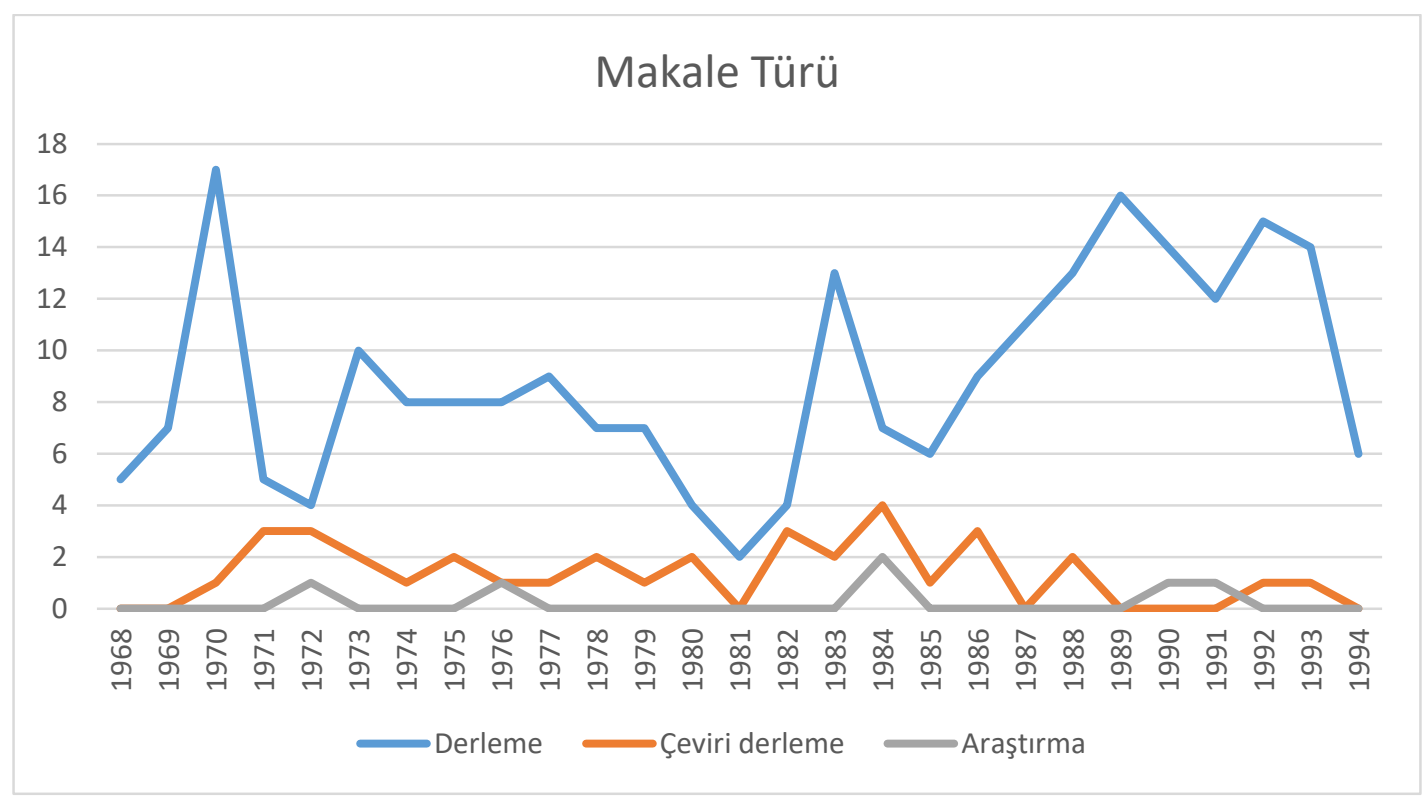

Şekil 1. Yullara Göre Yayınlanan Makalelerin Teknik Özellikleri

Şekil 1'de yer alan sonuçlar yıllar içerinde dergide en fazla oranda derleme türü yayınların basıldığ1 ve bunun derginin yayın süreci olan 27 yıl boyunca da sürdüğ̈ görülmektedir. Nitel veya nicel verilere dayalı araştırmaların sadece 1972, 1976, 1984,1990 ve 1991 yıllarında birer adet olarak yayınlandığı görülmektedir. Dergide araştırmaya dayalı yayınların sınırlı olduğunu akademisyenler görüşmelerinde de ifade etmişlerdir. Derginin o yıllarında yazar ve aynı zamanda okuyucusu olan akademisyen 2 aşağıdaki sözleri ile bu durumu açıklamıştır.

[O yıllarda] Bu alanın yetişmiş çok az sayıda elemanı vardı ve onlar da daha çok bu alana duydukları ilgiyi toplumla paylaşma çabası içindeydiler. Dergi daha çok dernek yönetimine yakın kişilerin ve eski öğretmenlerin yazılarını içeriyordu. Burada bir bilimsel yayın türünden söz etmek oldukça güç.

$\mathrm{Bu}$ ifadelerde belirtildiği gibi o yıllarda okul öncesi eğitimi alanında yetişmiş akademisyen sayısının az olması yayınlanan araştırma makalelerinin sayıca az olması ile ilişkilendirilmektedir. Dergide makaleleriyle yer alan yazarlar incelendiğinde; 1968-1994 yılları arasında toplam 106 yazarın dergide yayın yaptığı, bu yazarların arasında çevirmenlerin, psikologların, doktorların, diyetisyenlerin, öğretmenlerin ve milli eğitim müfettişleri gibi farklı meslek gruplarının temsilcilerinin yer aldığı görülmektedir. Özellikle derginin yayın hayatına başladığı ilk yıllarda yazarların çoğunun her sayıda farklı makaleleri göze çarparken; yetişmiş alan uzmanlarının sayılarının artmasıyla derginin yazar profili de değişmiş ve son sayılarda akademisyenlerin, çocuk gelişimi uzmanlarının isimlikleri sıklıkla yer almaya başlamıştır. Bununla beraber akademisyen 2, okul öncesi eğitimi dergisinde yayınlanan derleme ve çeviri gibi farklı türlerde makalelerin bilimsel odaklı olmadığını ancak güncel alan dergilerinin farklı türlerde makale yayınlamalarının yararlı olabileceğini aşağıdaki ifadeleriyle dile getirmiştir. 
Bugün de bu tür yayınlara yer verilebilir. Ama o zaman da derginin yayın kriterlerinde değişikliğe gitmek gerekir. Belki de alanda bizzat çalışan akademisyenlerin de bulunması bu ihtiyacı karşılıyor diye düşünülebilir. Ara ara geçmiş tecrübeleri anlatan yayınlar da gençler için faydalı olabilir.

\section{Makalelerin İçerik Özelliklerine İlişkin Bulgular}

Okul Öncesi Eğitimi Dergisinde 1968- 1994 yılları arasında yayınlanan makalelerin içerik özellikleri makalelerin hedef aldıkları yaş grubu, inceledikleri konu alanları ve amaç ve öneriler kapsamında incelenmiştir.

\subsection{Makalelere Konu Olan Yaş Grupları}

Yaş grupları 0-2 yaş, 3-6 yaş ve 0-18 yaşlarını kapsayan genel çocukluk olarak üç farklı gruba göre kodlanmış ve sonuçlar Şekil 3’te gösterilmiştir.

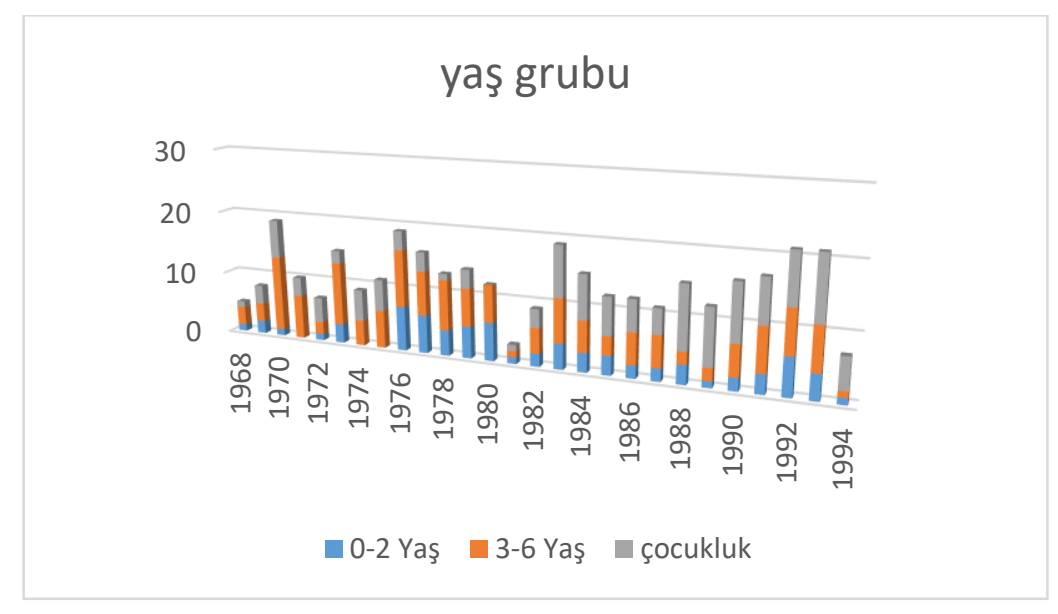

Şekil 2. Yıllara Göre Yayınlanan Makalelerin Hedef Aldıkları Yaş Grubu

Şekil 2'de görüldüğü üzere, dergide yayınlanan makaleler 80'li yıllara kadar en fazla 3-6 yaş dönemini hedef almışlardır. Bununla beraber 1984 ve 1994 yıllarında çocukluğu bütün bir dönem olarak ele alan makalelerin sayısı artmıştır. Öte yandan, 0-2 yaş grubunu hedef alan makalelerin sayısı diğer yaş gruplarına göre daha azdır.

\subsection{Makalelerin İnceledikleri Konu Alanları}

Okul öncesi eğitimi dergisinde yayınlanan makaleler genel olarak gelişim, eğitim, sağlık ve annebaba eğitimi olmak üzere dört farklı alanda kodlanmış ve yıllara göre sonuçlar Şekil 3’te gösterilmiştir. 


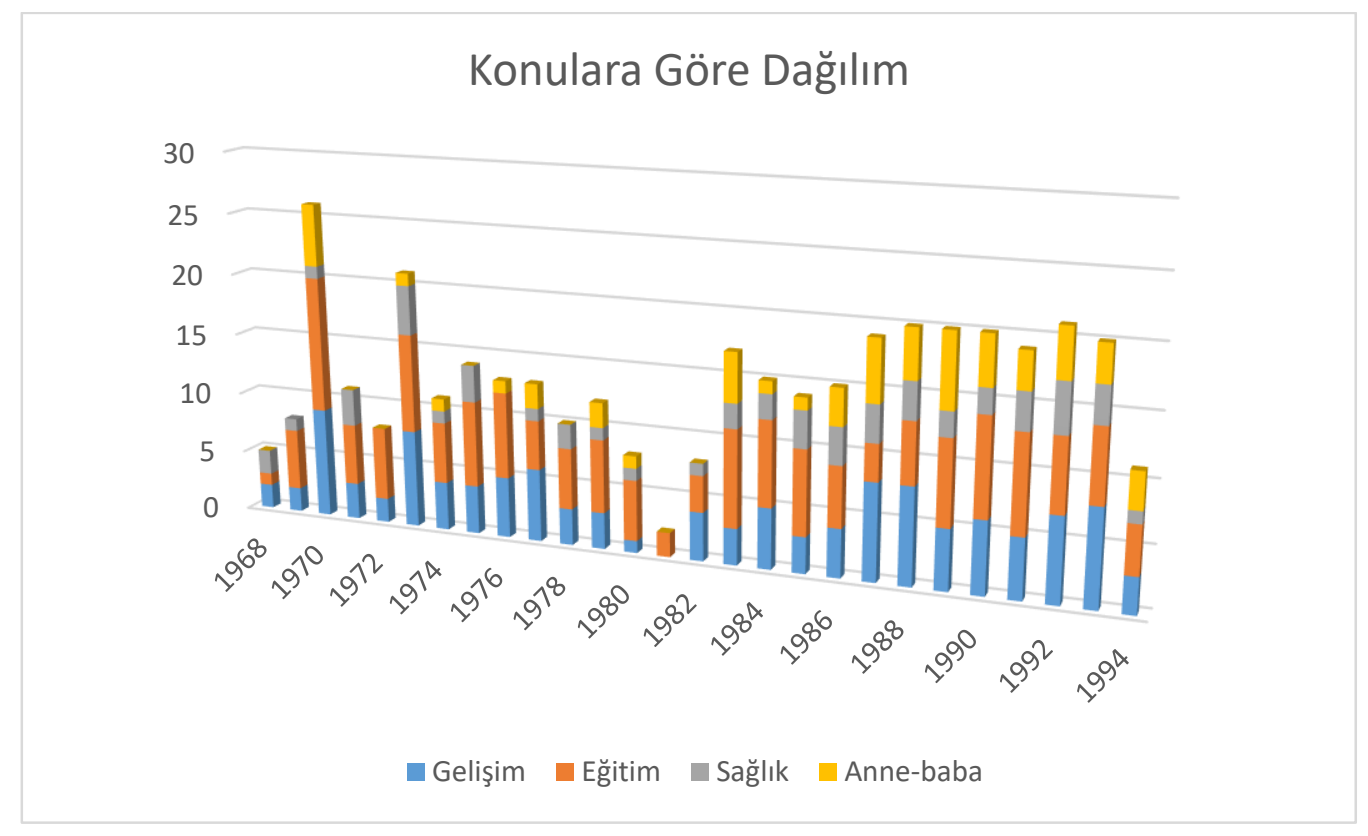

Şekil 3. Yllara Göre Yayınlanan Makalelerin Konu Özellikleri

Şekil 3’te yer alan sonuçlar makalelerdeki konu dağılımının yıllar içerinde geçirdiği değişimleri göstermektedir. Konu dağılımı incelendiğinde gelişim ve eğitim konularında basılan makalelerin dönemin ihtiyaçlarına ve gündem konularına da uygun olarak- anne-baba ve sağlık konularından daha geniş kapsamlı yer aldığını ve bu ilginin yıllar içinde yerini koruduğunu söylemek mümkündür. Derginin son 10 yıllına bakıldığında ise gelişim ve eğitim ile ilgili makalelerin sayısının neredeyse eşitlendiği görülmektedir. Bununla beraber anne-babayla ilişkili makalelerin sayısı giderek artarak sağlık alanında yazılan makalelerin sayısını geride bırakmıştır. Akademisyen 2 o dönemde dergide yayınlanan makalelerin konularıyla ilgili olarak aşağıdaki ifadeleri ile konulardaki dağınıklı̆ga dikkat çekmiştir.

İşte dergiye baktığınızda hocaların farklı konularda yazı yazdığını göreceksiniz. Demek ki dert etmemişler onlar da... Ne buldularsa onu tercüme etmişler koymuşlar. Bu okul öncesi eğitim alanının bilimsel olarak konuşmak gerekirse daha bocalama döneminde olduğunu gösteriyor. Yani, “ne dert?” daha ne onu anlamamışız. Niye biliyor musun? Biz çocuk gelişimi eğitimcileri olarak büyüdük orda 3-18 yaş, daha 36 yaşa odaklanmadık. Sonra giderek biraz daha başlık değişti, yazılar daha bir değişti ama hakem kurulu var mıydı, yok muydu, dersen yoktu. Yönetim kurulu bakıyordu yazılara, dolayısıyla hata bulabilirsiniz o yazılarda. Çünkü oradaki herkes uzman değil. Hoşşimdiki dergiler uzman mı, soru işareti. Tekrar bu yüzden kutluyorum dijitalleşme yok hakem yok, hiçbir şey yok kusura bakmayın, kimse editör değil.

\section{Makalelerin Amaç ve Önerileri}


Yayınlanan makalelerin amaç ve önerileri detaylı incelenmiş; üç temel tema ve bunların alt temaları oluşturulmuş ve Şekil 4'te gösterilmiştir.

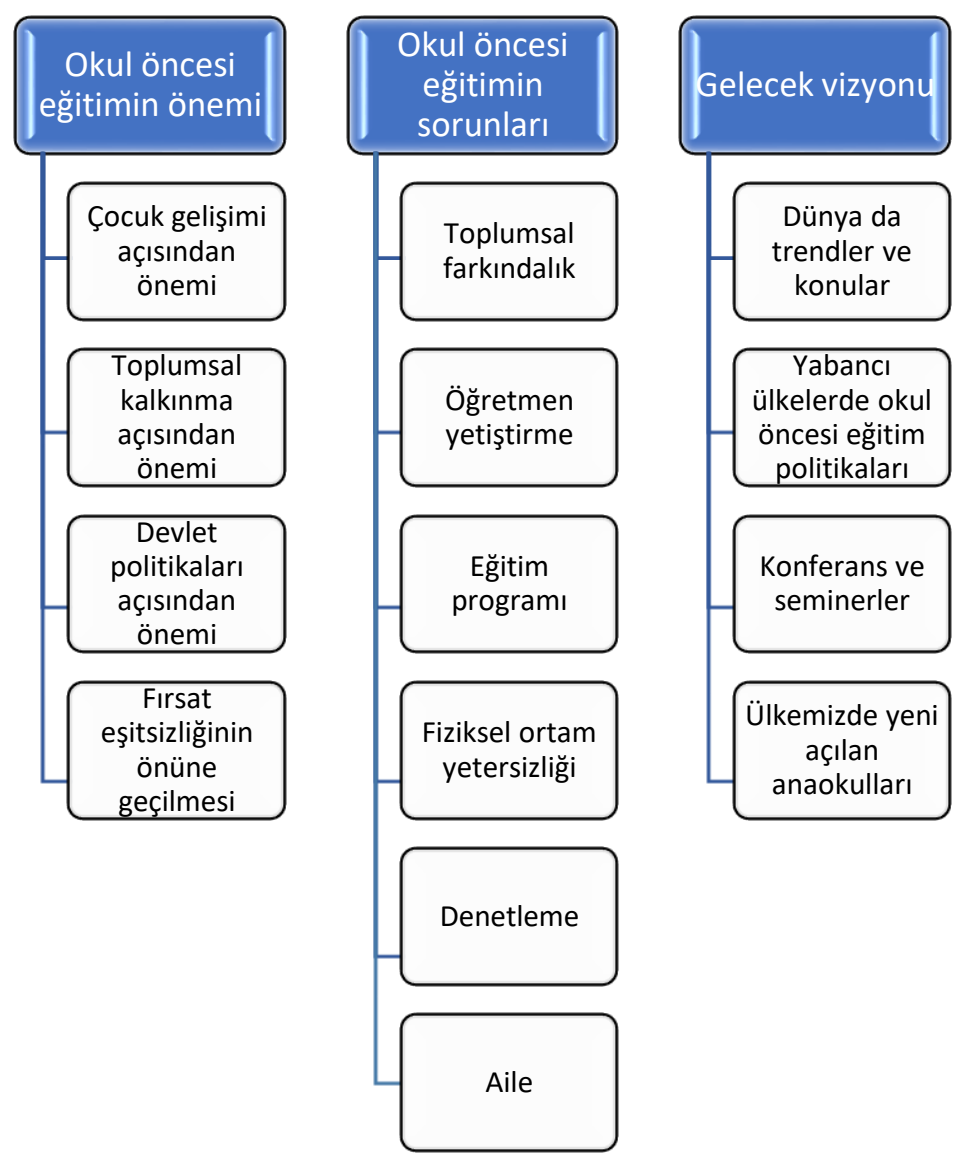

Şekil 4. Yayınlanan Makalelerin Amaç ve Önerileri

\subsubsection{Okul Öncesi Eğitimin Önemi}

Şimdi dergiyle ilgili şunu söyleyeyim bak diş sağlığı var, psikoloji var, motor gelişim var, o var bu var. Aslında ilk önce okul öncesi eğitimin önemi var dikkat ettiyseniz. Çünkü dert oydu kimse bilmiyordu okul öncesi eğitim neydi. Anaokulu örnekleri var etkinlik örnekleri var, iyi bir okul nasıl olmalı var, sorunlu çocuk var, yok yoktu o zamanlar için bu dergide. (Akademisyen 2)

Okul öncesi eğitim dergisi okul öncesinin toplumda henüz yaygın olarak tanınmadığı dönemde önemli bir tanıtma misyonu üstlenmişti. O dönemde dergiyi çıkaranlar çok sınırlı bir grupla yayın yapıyorlardı. Çok geniş̧ bir kitleye ulaşamasalar da alanda yeni çalışmaya başlayanların ilgisini çekebildiklerini düşünüyorum. (Akademisyen 1)

Yukarıda katılımcı akademisyenlerin ifade ettiği gibi Okul Öncesi Eğitimi Dergisi çok farklı konularda yayınlar yaparken temel vurgusu, bu eğitim kademesini tanıtmak ve öneminin anlaşılmasını sağlamak olmuştur. 1968-1994 yılı arasındaki yayınlanan makaleler 
incelendiğinde okul öncesi eğitimin (1) çocuk gelişimi, (2) toplumsal kalkınma (3) devlet politikaları ve (4) fırsat eşitsizliğinin önüne geçilmesi açılarından önemli olduğunu savunan çalışmalara yer verildiği görülmektedir. Bu çalışmalara dergide yer verilme sıklıklarının; dönemsel ihtiyaçlara, dünyada erken çocukluk eğitimi alanındaki gelişmelere ve yönelimlere paralel bir şekilde değiştiği görülse de derginin temel vurgusunu ilk sayısından son sayısına kadar koruduğunu söylemek mümkündür.

Okul öncesi eğitiminin çocuk gelişimini destekleyici bir eğitim olduğu 121 farklı makalede belirtilmiştir. Bu makalelerde okul öncesi eğitimin; psikomotor, sosyal-duygusal, bilişsel, dil gelişimi ve öz bakım becerilerini desteklediği tartışılmıştır. Bilişsel gelişim ile ilgili çocukların dikkat süreleri, ilgi alanları kavram öğretimi, oyunun etkisi ile ilgili makaleler yer alırken; dil gelişimi ile ilgili ise çocukta dil gelişim evrelerini, okul öncesi eğitimin dil gelişimine olan etkisini, öğretmenlerin dil gelişim etkinliklerini planlarken göz önünde bulundurması gereken noktaları içeren makaleler göze çarpmaktadır. Örneğin, Tunç (1974, s.17) okul öncesinde anadil öğreniminin önemini anlattı̆̆1 makalesinde “çocuğun beyin gelişiminin \%85'inin 6 yaşa kadar tamamlanmasına rağmen çocuğun anadilini programlı bir şekilde doğru ve düzgün öğrenmesinin 7 yaşından başlaması bir handikaptır” ifadelerini kullanarak erken öğrenmenin gelişimi desteklemek için önemli olduğunu o yıllarda vurgulamaktadır.

Yayınlanan makalelerde sosyal-duygusal gelişim için okul öncesi eğitim basamağının olmazsa olmaz olduğundan bahsedilmiş; çocukların akranlarıyla aynı yerde bulunmasının önemine, sosyal hayata dair kuralların rol model alma ve akran ilişkileriyle öğrenilmesinin daha kolay olmasına, çocuğun problem çözme, duygularına anlama ve ifade etme gibi becerileri edinmesine olan etkisine vurgu yapılmıştır. Psikomotor gelişim ve öz bakım becerilerine de değinen makaleler; genel olarak çocuğun hareket alanlarının güvenliğine, kısıtlanmamış olmasına, etkinlikler yoluyla desteklenmesine ve okul öncesinin temel bir hayata hazırlık programı içermesine odaklanmışlardır. Ayrıca iyi bir okul öncesi eğitim kurumunun çocuğa; yemek, uyku, tuvalet ve temizlik gibi temel alışkanlıkları kazandırmasına yardımcı olduğu belirtilmiştir (Gönen, 1990, s.6). Örneğin Kantarc1oğlu (1973, s.6) "Neşe mesleki bir fazilettir" ifadesini kullanarak; çocuğu sevmenin onu cici bulmak değil, onu anlamak, mutluluğunu sağlamak, temiz ruhuna sayg1 göstermek ve çevreyi ona göre düzenlemek olduğunu belirtmiş ve çocuğun sosyal-duygusal gelişiminin ancak böyle destekleneceğini önermiştir. Benzer şekilde, y1llar içinde Armaner (1982, s.11) çocuğun okul öncesi dönemde kurduğu ilişkilerin gelecek yıllarda kuracağı ilişkileri olumlu etkileyeceğinden, Haktanır ise 
(1991, s.23) okul öncesi eğitim alan çocukların paylaşmaya daha yatkın, kendi haklarını savunabilen ve sorumluluk alabilen bireyler olacağından bahsetmiştir.

Okul öncesi eğitiminin toplumsal kalkınma açısından önemine değinen makalelerde sıklıkla; okul öncesi eğitimin örgün eğitimin ilk basamağı olması gerektiğine, küçük yaş grubu çocukların okula ne kadar erken başlarsa formal eğitime devam etme olasıllğının o kadar artacağına, toplumsal kalkınmayı sağlamak için önce çocuğu anlamak ve çocuğa yatırım yapmak gerektiğine vurgu yapılmıştır. Tural (1977, s.16); çocuğun çeşitli ihtiyaçlarını belirleyen ve çocuğu önemli görerek erken eğitim veren ülkelerin daha hızla geliştiğini belirtirmiştir. 80’li y1llarda yayınlanan çeviri makalesinde Hymes (1980, s. 21) ise; dört yaş çocuklarının da uygun büyüklüklerde sınıfla, uygun araç gereçle ve çocuklarla olduğu kadar anne-babalarla da çalışmak üzere eğitilmiş iyi eğitimli öğretmenlerle çocuk yuvalarına alınmaları gerektiğini anlatmıştır. Bu makalede bu çocuklar uzun yıllar sonra daha verimli, daha barısssever kimseler olarak, onlar için harcadığımız parayı bize geri getireceklerdir ifadesi vurgulanarak, erken öğrenmenin toplumsal kalkınmaya olan etkilerine dikkat çekilmiştir. Benzer şekilde Eren (1987 s.6) okul öncesi eğitimin yaygınlaştırılmasının suça yönelmiş ve bunalıma düşmüş çocukların topluma kazandırılmasında büyük önem arz ettiğine dikkat çekmiştir.

Okul öncesi eğitimin devlet politikaları için ve firsat eşitsizliğinin önüne geçilmesinde önemli bir konu olduğu dergide yayınlanan makalelerde yer almaktadır. O dönemde yazarlar devlet politikalarına yönelik zorunlu eğitim yaşının erkene çekilmesi, okul öncesi eğitimine ilişkin politikalar uygulanması, okul öncesi eğitimin ilkokulun bir alt basamağı değil başlı başına bir eğitim programı olarak ele alınması, diğer eğitim kademelerine verilen önemin okul öncesi eğitim basamağına da verilmesi, öğretmen yetiştirme politikalarının revize edilmesi, okul öncesi eğitim kurumlarına yönelik denetçilerin yetiştirilmesi, yeni anaokullarının açılması ve okul öncesi eğitimin tek bir bakanlığa bağlanması gibi konularda önerilerde bulunmuşlardır. Örneğin, Tulay (1971, s. 7) makalesinde; “Toplumların geleceği çocukluğun ilk yıllarına verilen değerin ve harcanan emeğin ölçüsü ile orantılıdır. Toplum hayatımızda çözüm bekleyen ilk düğüm okul öncesi eğitimi konusudur” cümleleri ile bugün hala eğitim politikalarında çözümlenmemiş okul öncesi eğitiminin yaygınlaşmamasından bahsetmektedir.

Okul öncesi eğitiminde firsat eşitsizliğine dikkat çeken Bekman (1991, s.4) "Kurumların çoğunun özel ve ücretli olması nedeniyle, en çok gereksinim duyan toplum kesimine az, en az gereksinim duyan kesime ise daha çok hizmet götürülmektedir” ifadesiyle okul öncesi 
eğitimine en çok ihtiyaç duyan sosyoekonomik olarak dezavantajlı çocukların bu eğitimin ücretli olması nedeniyle yeterince yararlanamadıklarını dile getirmiştir.

\subsubsection{Okul Öncesi Eğitimin Sorunları}

Dergi yayın hayatına başladığı günden 1994'e kadar okul öncesi eğitimin öneminin yanı sıra bu alanın sorunlanına değinmiş ve çözüm önerileri üretme misyonunu üstlenmiştir. Makalelerde ele alınan sorunlar arasında toplumsal farkındalık oluşturulamaması, öğretmen yetiştirme ve eğitim programları hakkındaki sorunlar, fiziksel ortam yetersizliği, denetleme ve aile katılımının sağlanmaması konuları dikkat çekmektedir. Aynı zamanda bu başlıklarda belirtilen sorunların birbiriyle olan ilişkileri de makalelerde ele alınmıştır. Örneğin küçük yaş grubu çocuklar için özerk programlar oluşturulması sorunu bu programların öğretmen yetiştirme programlarının da değişmesi gerektiğini ortaya koymuştur. Örneğin; Saray (1970, s.16), "eğitimde milli bütünlüğün olması gerektiği ve öğretmen yetiştirmede kaynak farklılığının önüne geçilmesi gerektiğini” anlatırken; bundan yaklaşık 20 yıl sonra Bekman (1991, s.7) ise okul öncesi eğitim kurumlarının örgütlenmelerinin hala bürokratik açıdan sorunlar taşımakta olduğunu ve Türkiye'de okul öncesi eğitimcilerinin yetiştirilmesinde genel bir dağınıklığın gözlemlendiğini belirtmiştir. Kantarcıoğlu (1988, s.6) “okul öncesi eğitim zorunlu öğrenim çağı içerisine alınmadığı ve anaokulları ve anasınıflarının ihtiyaçları bir program dahilinde devlet tarafindan belirli bir ödenekle karşılanmadığı sürece okul öncesi eğitimin istenilen düzeye ulaşamayacağına" dile getirmiştir.

Yukarıda değinilen öğretmen yetiştirme ve okul öncesi eğitimin yaygınlaştırılması ile ilgili sorunların yanı sıra eğitimin niteliğine yönelik olarak çocuk merkezli eğitim, günlük akış, çocuğa görelik gibi kavramlar yayınlarda gündeme getirilmiştir. Baymur (1969, s.7) “özel anaokullarının ve çocuk yuvalarının açılması her ne kadar iyi birer adım olsa da bunların çoğu bina, araç ve öğretmen bakımından yeterli değildir. Bu sebeple iyi yetişmiş, bilimsel rehberlik yapabilecek öğretmenlere, fiziksel ortamların düzenlenmesine, araştırmalar yapılmasına ihtiyaç vardır" ifadeleri ile sorunlara dikkat çekerken; 21 yıl sonra Gönen (1990, s.7) “anasınıfı ve anaokullarının yalnızca büyük kentlerde hizmet verebilmekte olduğunu gerek bina eksikliği gerekse bu konuda yetişen öğretmen ve uzman yetersizliği nedeniyle ülke çapında faaliyete geçilemediğine" vurgu yapmaktadır. Bununla beraber okul öncesi eğitim kademesinde denetim problemleri yaşandığı da araştırmalarda sıklıkla vurgulanan konulardandır. Kantarcıoğlu (1988, s.4) “Okul öncesi eğitim kurumlarında çalışan tecrübeli, başarılı öğretmenler hizmet içi eğitimden geçirilerek, hatta imtihanlardan geçirilerek rehberlik ve 
denetleme görevlerine tayin edilebilmelidir" diyerek devlet politikalarına yönelik önerilerde bulunmuştur. Farklı alanlarda uzmanlaşmış kişilerin okul öncesi eğitim alanında denetim rolü üstlenmesine eleştiri getiren Bekman (1991, s.7); okul öncesi eğitim alanının ilkokul eğitimden farklı olduğunu, denetimin okul öncesi eğitim alanında uzman kişiler tarafindan yapılması gerektiğini ifade etmiştir.

Okul öncesi eğitimin sorunlarını ele alan makaleler; ailelerin okul öncesi eğitime yönelik algılarının değişmesi gerektiği, aile-okul iş birliğinin önemi ve aile eğitiminin okul öncesi eğitiminin bir parçası olması önerilerine yer vermişlerdir. Derginin ilk sayılarından itibaren toplumda yaygın olan okul öncesi eğitiminin çocuk bakım merkezi algısı ile mücadele edilmeye başlanmıştır. Varış (1968, s.7) makalesinde “Günümüzde okul öncesi eğitimini ailenin fonksiyonun yedeği değil yaygın bir devamı olarak görmek gerekecektir” ifadeleri ile okul öncesi eğitiminin ailedeki çocuk bakımının bir yedeği olmadığı vurgularken; iki yıl sonra Oral (1970, s.15) "Ailenin anaokullarını bakıcı kurumlar olarak görmekten vazgeçmesi ve iletişime açık olması gerekir” ifadesiyle doğrudan ailelerin bakıcı algısının değişmesi gerektiğini savunmuştur. Haktanır (1991, s. 22) ebeveynlerin bir kısmının okul öncesi eğitim hakkında bilgi sahibi olmadıkları için beklentilerinin de şekillenemediğini belirtirken bu durumun çözümünü “ailenin ve çevrenin ne beklediğini bilmek, taviz vermeden, istismar etmeden, ayrıcalık yaratmadan çocuğa yön vermek ve aileye yardımcı olmak için okulun güçlü ilişkiler kurması gerekmektedir” olarak açıklamıştır. Ömeroğlu (1994, s.6) ise "ebeveyn her zaman eğitimcinin en büyük yardımcısıdır" ifadesini kullanmıştır. Yukarıdaki örneklerden de anlaşılacağı gibi, dergi ilk sayısından son sayısına kadar hem ailelerin okul öncesi eğitim açısından önemine değinmiş hem de okul öncesi eğitimin aile eğitimi için olmazsa olmaz olduğuna vurgu yapmıştır.

Değişen toplum yaşantısı, annelerin çalışma hayatına atılması ve hatta annelerin çağın önemini kavrayacak şekilde eğitilmemiş olmasının okul öncesi eğitimin gerekliliğine kanıt olarak sunulduğu makaleler göze çarparken; "Çocuklara yönelik belirlenen hedefler ve saptanan politikalar kuşkusuz ki öncelikle aileyi temel almak ve aile kurumuna yönelmek durumundadır. Çünkü aile çocuğun ihtiyaçlarını karşılayan, büyüten, yetiştiren, onu yarınlara hazırlayan ilk ve en önemli toplumsal birimdir (Yeşilyaprak, 1990, s.4)" ya da "Ebeveyn bir başvuru kaynağ1 ve çocuğun ilk eğitimcisidir (Ömeroğlu, 1994, s.5)" gibi söylemlerle de ailenin çocuğun hayatındaki yerine ilişkin makalelere rastlamak da mümkündür. Araştırmanın katılımcıları da derginin yayınlarının o dönemde okul öncesi eğitimi sorunlarına dergideki 
yayınların ışık tuttuğunu vurgulamışlardır. Akademisyen 2 aşağıdaki ifadelerinde durumu açıklamaktadır.

Hızlıca baktım biz o zamanlar baya güzel şeyler yazmışı, ama sorunlar aynı devam ediyor. Öğretmen niteliği, aile sorunları, ortam niteliği devam ediyor, hiçbir şey değişmemiş. Yani bu kadar yazıya bu kadar yayına biz bir gram ileri gidememişiz gibi geliyor ve bu da utanç verici.

Okul Öncesi Eğitimi Dergisinin o dönemde alan sorunlarına değindiği ancak günümüzde bu sorunların tamamıyla çözüme kavuşmadığını dile getirirken, Akademisyen 2 dergi yöneticilerinin alanın sorunlarının yetkililere açıklanmasında aktif rol oynadıklarını da belirtmiştir.

Derginin okul öncesi eğitimi politikalara direk etkisi yoktu ancak, her dönem bakanlığa giderdik biz buyuz derdik.... Biz sizinle ilgili hiçbir şey duymadık derlerdi. Her dönem yeniden başlardık. Elimizden geldiğince uğraştık, her yerde bulunduk, bunun sonucunda da beraber kongreler yaptık, yurtdışı incelemeleri yaptik.

\subsubsection{Okul Öncesi Eğitimde Gelecek Vizyonu}

Okul öncesi eğitimi dergisinde yayınlanan makalelerinin amaç ve önerilerinin analizinden elde edilen son alt tema yayınların alanın geleceğine dair önerilerini içeren gelecek vizyonu olarak adlandırılmıştır. Bu tema altında (1) Dünya'da trend olan konular, (2) yabancı ülkelerden okul öncesi eğitim politikaları ve modelleri, (3) seminer ve konferansların metinleri çevrilmiş ve yayınlanmıştır. Ayrıca aileler için yeni açılan anaokulları tanıtılmış ve örnek uygulamaları okuyucularla paylaşılmışır. Örneğin Bromham’ın (1971, s. 14) çeviri olarak yayınlanan makalesinde "müziğin bilinçli kullanımının çocuğun uyum sorunlarıyla başa çıkmasına ve dengesizlik yaşayan çocukların adapte olmasına yardımcı olacağına değinilmiş erken çocuklukta müziğin terapötik amaçla kullanımı önerilmiştir. On yıl sonra farklı bir sayıda Herbienere-Lebert'in (1980, s.14) çeviri makalesinde herhangi bir imge olmadan yalnızca dinleyerek öğretmenin çocukların hayal güçlerini ve dikkat becerilerini geliştirebilir denilerek anaokullarında okul radyosu kurulabileceği önerisine yer verilmiştir. 1988 yllında ise Woodill (s.15) tarafından kaleme alınan makalede, okul öncesi eğitim personelinin bilgisayar kullanımından korkmaması ve erken çocuklukta bilgisayarın kullanımı ile ilişkili çalışılması gerektiğine dikkat çekilmiştir. Ayrıca Almanya, Finlandiya, İsviçre, Kuveyt, İtalya gibi çeşitli ülkelerdeki okul öncesi eğitim politikaları, öğretmen yetiştirme programları ve ailelerin çocuk yetiştirme tutumlarını açıklayan makalelere yer vermiştir. 
Araştırmacılar, öğretmenler ve ebeveynler için o çağın yeniliklerini tanıtan makalelerin dergi kapsamında yayınlandığı görülmektedir. Genel olarak 1960’lı yıllardan başlayarak o dönemin koşullarında dergide yayınlanan makalelerin geleceğe dair olumlu bir başlangıç yaptıkları belirtilirken, katılımcı akademisyenler güncel yayınlardaki bazı eksikliklere dikkat çekerek önemli öneriler sunmuşlardır. Örneğin Akademisyen 2;

Şimdi unvan kaygısı nedeniyle kısa kısa, nitelik kaygısı olmadan araştırmalar yapılıyor. Bulmuşlar kısa kısa ölçekleri, bunla bu, bunla bu, al sana ilişkisel tarama. Dünyanın verisini toplamışlar, milyon tane bulgu, şu kadarcık tartışma... Başlığın konuyla alakası yok, özette bulgu yok, ne yapılmış yok, önerilere bakalım annelere bu konuda eğitim verilmelidir diyor. Ama kim? Nasıl? Kime? Hedef kim belli değil? Bulgulara bakıyorsunuz onla bunun arasında bu var, şu var, ama neee? Anlaşıllır bir şey yok. Yorum yapmiyorlar o bunu demiş, bu bunu demiş, ama araştırmacının kendisi ne demiş o yok.

Okul öncesi eğitimi alanında yapılan güncel akademik yayınların bu dergideki makalelerde olduğu gibi toplumsal bir misyonu okuyucuya taşımak yerine bireysel kaygılarla daha çok unvan almak amacıyla yapılması katılımcı akademisyenler tarafindan eleştirilmiştir. Akademisyen 1 yayınlardaki benzer sorunlara değinirken çözüm önerisi de sunmuştur.

Artık sadece unvan almak için kısa süren, küçük çaplı çalışmalar değil, ülkenin gerçek sorunlarına somut çözümler bulabilmek için, disiplinler arası ve büyük ölçekli, kapsamlı projelerin yapılması gerekiyor.

\section{SONUÇ ve TARTIŞMA}

Okul Öncesi Eğitimi Dergisinde yer alan makalelerin tarihsel süreç içinde derinlemesine incelendiği bu araştırma Türkiye de okul öncesi eğitiminin gelişim sürecine ve değissimine ışık tutmaktadır. Okul Öncesi Eğitim Dergisinin 52 sayıda yer alan toplam 283 makalesiyle yayınlandığı dönem içerisinde okul öncesi eğitimin gelişimine büyük ölçüde destek verdiği görülmektedir. Okul öncesi eğitimiyle ilgili politikalar hakkında bilgilendirici yayınlar yapması, yurtdışındaki akademik yayınları çevirerek dile kazandırması ve yurtiçinde yeni tartışılmaya başlanan konuları okuyuculara bilimsel bir temel üzerinden sunması Okul Öncesi Eğitimi Dergisini tarihsel süreç içerisinde önemli kılmaktadır.

Araştırmada ilk olarak makaleler teknik özellikleri açısından incelenmiş ve araştırma makalelerinin sınırlı olduğu, çeviri ve derleme makalelerinin ise ağırlıklı olarak yayınlandığı belirlenmiştir. Derginin yayına başladığı 1968'li yıllarda okul öncesi eğitiminin akademik olarak yapılanmamış olması bu durumu açıklamaktadır. 1992 yllında eğitim fakültelerinde okul öncesi eğitimi öğretmenliği programlarının açılması alanda akademisyen yetişmesini ve akademik yayınların artmasını desteklemiştir (Kavak, Aydın ve Akbaba-Altun, 2007; Kıldan ve Ahi, 2013). 2006-2017 yılları arasında okul öncesi eğitimi alanında yayınlanan araştırmaların içerik özelliklerinin incelendiği 
güncel bir araştırmada nicel yöntemlerin daha çok tercih edildiği, deneysel araştırma yöntemlerinin ve doğrudan çocuklarla çalışılan araştırmaların sayısının da yıllar içerisinde artmaya başladığı vurgulanmıştır (Çiftçi ve Ersoy, 2019).

İkinci olarak makalelerin içerik özelliklerine bakıldığında; yapılan araştırmaların en fazla 3-6 yaş grubu çocuklara yönelik olduğu, bebeklik dönemi olarak kabul edilen 0-2 yaş çocuklarını hedef alan makalelerin ise sayıca çok az olduğu görülmektedir. 1967'deki II. Beş Yıllık Kalkınma Planında okul öncesi eğitimin 3-6 yaş aralığındaki çocukların eğitimi olarak tanımlanmasının (DPT, 1967) ve sonrasında Millî Eğitim Bakanlığının okul öncesi eğitim kurumuna kaydolma yaşını 36-72 ay olarak belirlemesinin yayınların ağırlıklı olarak bu yaş grubu çocuklara yönelmesine neden olduğu düşünülmektedir. Ancak 0-3 yaş çocuklarının eğitimine yönelik akademik yayınların azlığı hala alanda önemli bir sorun olarak geçerliliğini korumaktadır. Güncel araştırmalar, erken çocukluk döneminin insan gelişimine temel oluşturacak becerilerin ve alışkanlıkların kazanıldığı kritik bir dönem olduğunu ortaya koymaktadır (Oktay, 1990; Britto, Engle \& Super, 2013; Sylva, Melhuish, Sammons, Siraj-Blatchford \& Taggart, 2010). Boylamsal araştırma sonuçları nitelikli bir erken çocukluk eğitiminin, kısa vadede akademik başarıyı, uzun vadede ise eğitim ve gelir düzeyinde yükselme, suç işleme oranında azalma gibi yaşam boyu olumlu etkileri olduğunu göstermektedir (Schweinhart, Montie, Xiang, Barnett, Belfield, \& Nores, 2004; Sylva, vd., 2010). Bu nedenle 0-3 yaş grubu çocukların eğitimlerini hedef alan akademik yayınların artması toplumda erken öğrenmenin önemine dikkat çekecek ve sağllklı bir toplumun inşa edilmesine destek olacaktır.

Üçüncü olarak dergide yayınlanan makalelerin konuları incelendiğinde; çocuk gelişimi, eğitim, annebaba eğitimi ve sağlık konularını ele alan yayınların olduğu görülmektedir. Bu bulgu güncel araştırma analizi çalışmalarının sonuçları ile de desteklenmektedir. Örneğin Çiftçi ve Ersoy (2017) okul öncesi eğitim araştırmalarında sıklıkla ele alınan konuları sıraladıkları makalelerinde; gelişim alanları ve öğretim materyallerini konu alan yayınların sayıca fazla olduğunu; özel eğitim, matematik eğitimi gibi alanlarda ise daha az araştırma yapıldığını belirtmişlerdir. Benzer şekilde; Altun, Şendil ve Şahin (2011) ise okul öncesi eğitim alanındaki lisansüstü çalışmaları incelemiş ve eğitim konularına sıklıkla yer verilse de sınıf yönetimi, üstün zekâlı çocukların eğitimi, baba katılımı, çocuk hakları gibi çeşitli konuların alanda ihmal edildiğini ifade etmişlerdir. Yine, güncel bir dergi analizinde, Doma ve Toran (2020) 1986-2015 yılları arasında Yaşadıkça Eğitim Dergisinde en çok anne-baba eğitimi konusunu ele alan yayınların bulunduğunu belirtmişlerdir. Bu bilgilerin 1şı̆̆ında 50 yıldan fazla bir süredir alan yazınında eğitim, çocuk gelişimi ve anne-baba eğitimi gibi temel konuların hala araştırıldığını söylemek yanlış olmayacaktır. Bu doğrultuda teknoloji, medya, yeni eğitim modelleri, program değerlendirme, deneysel program geliştirme, dini ve kültürel etkilerin incelendiği araştırmaların alan 
yazına kazandırılması; aynı zamanda alanda yeni trendler oluşturacak, kültürel ve evrensel değerleri geliştiren, özgün gelişim ve eğitim modellerini ortaya koyan, alandaki sorunlara pratik çözüm önerileri sunan araştırmaların sayılarının da arttırılması önerilmektedir.

Dördüncü olarak Okul Öncesi Eğitim Dergisinin yayınlandığı günden beri makalelerin odaklandığı; okul öncesi eğitimin öneminin anlaşılamaması, yaygınlaştırılamaması, zorunlu eğitim kapsamına alınmaması ve geleneksel öğretmen merkezli eğitimden çocuğun gelişim ve ihtiyaçlarını temel alan çocuk merkezli eğitim anlayışına geçiş yapılamaması gibi temel sorunların hala geçerliliğini koruduğu görülmektedir. Çeşitli güncel araştırma sonuçları bu sorunları tekrar tekrar ortaya koymaktadır (Ayyıldız ve Albayrak, 2020; Can ve Kılıç, 2019; Öztürk, Kaya ve Durmaz, 2015; Sabanc1, Altun ve Uçar Altun, 2018; Tuzcu, 2019;). Bu durum uzun süredir yayınlarda alandaki sorunların tespitine dayalı araştırmaların yapıldığını ancak çözüme dair bir gelissme kaydedilemediğini göstermektedir. Alandaki sorunların ortaya konulması önemli olmasına rağmen güncel araştırmalarda bunları tekrar etmek yerine sorunlara çözüm odaklı araştırmaların yapılması yararlı olacaktır. Özellikle yayınlar incelendiğinde; disiplinler arası araştırmaların, Millî Eğitim Bakanlığı, Aile, Çalışma ve Sosyal Hizmetler Bakanlığı gibi resmî kurumlarla ortak yapılan araştırmaların, ülkeler arası karşılaştırmalı araştırmaların, TÜBİTAK gibi bilimsel araştırma fonlarınca desteklenen büyük ölçekli araştırmaların geçmişte ve günümüzde sayıca sınırlı olduğu dikkat çekmektedir. $\mathrm{Bu}$ araştırmada da ortaya konulduğu gibi araştırmacıların bireysel yükselmelerini destekleyen, benzer sorunları ele alan, nicel yöntemlere dayalı makalelerin alanda genel bir trend oluşturduğu görülmektedir. Bu nedenle alanda araştırma ve yayın kalitesinin artırılması için bilimsel yayın yapan dergilerin güncel konularda araştırmaları desteklemek için düzenli olarak özel sayı çağrıları açmaları, araştırma alt yapısını güçlendirmek için araştırma modelleri ve trendleri ile ilgili uzmanların yazılarını yayınlamaları, kurum ve kuruluşlardan alınabilecek araştırma destekleri ile ilgili bilgileri içermeleri gibi alan dergilerinin yayınlarını çeşitlendirmeleri önerilmektedir. Alan dergilerinin editörlerinin ve alan uzmanlarının bilimsel toplantılarda alanda bilimsel gelecek vizyonu oluşturulması için fikir alışverişi panelleri yapmaları, araştırmacılar için yeni trendler oluşturmaları ve bunları dergilerde yayınlamaları oldukça önemlidir. Böylece genç araştırmacıların benzer konularda sürekli yayın yapmalarının önüne geçilebileceği gibi yeni araştırma trendleri de oluşturulabilecektir.

Beşinci olarak, sonuçlar süreli yayınların ulaşabildiği okuyucu kitlesinin sınırlı kaldığına ve araştırmaları okuyanların yine araştırmacılar olduğuna dikkat çekmektedir. Elli yıl önce yayınlanan bilimsel makalelerde ele alınan önemli bilgiler ülkemizdeki MEB gibi karar alıcılar ve ebeveynler, öğretmenler gibi uygulayıcılara ulaşmamıştır. Bu durum kanıta dayalı çözüm ve uygulamaların okul 
öncesi eğitim alanında yayınlaşmasının önünde bir engel oluşturmaktadır. Bu nedenle alandaki sorunlar çözümlenmediği için sürekli sorunları ortaya koyan benzer araştırmalar alan dergilerinde yayınlanmaktadır. Bugün teknolojik gelişmeler ve arşivleme politikaları sayesinde süreli yayınların erişilebilirliği her zamankinden daha fazla olmasına rağmen akademik dergilerin okuyucu kitleleri sınırlı sayıdadır. Alanında uzman araştırmacıların yaptıkları araştırmaların sonuçlarının okullardaki eğitim uygulamalarına yansıtılma imkânı sınırlı kalmaktadır. Bu nedenle alandaki bilimsel araştırma sonuçlarının somut, kısa, anlaşılabilir, akademik jargonlardan arındırılmış; amaç, sonuç ve önerilerini içeren özetlerinin alan dergilerinin sosyal medya sayfalarında yayınlanmaları önerilmektedir. Bu şekilde alan dergilerinin okuyucu kitlesi çeşitlendirilebilir, bilimsel makalelerin tanıtımları yapılabilir ve böylece çok daha fazla sayıda paydaşla bilimsel sonuçlar paylaşılabilir.

Son olarak okul öncesi eğitimi alanında yayın yapan dergilerin SSCI, SCI, AHCI gibi geniş kitlelere ulaşan tanınırllğı yüksek olan indekslerde taranmaması, araştırmacıları uluslararası dergilerde yabancı dilde yayın yapmaya yöneltmiş bulunmaktadır. Özellikle ülkemizde yapılan özgün ve kaliteli makalelerin yabancı dilde yayınlanması alan için önemli bir eksiklik oluşturmaktadır. En önemli paydaşlarımız olan öğretmenler, anne-babalar ve politika geliştiricileri yabancı dilde yayınlanan araştırmalardan faydalanamamaktadırlar. Bu nedenle alan dergileri uluslararası dergilerde yabancı dilde yayınlanan önemli makalelerin kısa özetlerini Türkçe olarak yayınlanmaları için yazarları teşvik edebilir.

Bu araştırma okul öncesi eğitimi dergisinde yayınlanan makaleleri inceleyerek geçmişten günümüze alan yazındaki değişim ve trendleri tanımlamış ve alanda hala önemli sorun olarak görülen konuların çözümlenmediğini ortaya koymuştur. Öte yandan, bu araştırmanın bazı sınırlılıkları bulunmaktadır. Özellikle o dönemde yayın yapan araştırmacılara ulaşmada zorluklar yaşanmış ve sadece iki akademisyen görüşleri ile çalışma sınırlanmıştır. Gelecekte yapılacak olan araştırmalar alanda duayen olarak kabul edilen deneyimli araştırmacıların alandaki araştırma trendlerine yönelik deneyim ve gelecek vizyonlarını inceleyebilir. Bekman (2005) Türkiye'de erken çocukluk eğitimi alanında önemli araştırmaların yapılmasına karşın bilimsel araştırmanın uzun bir geçmişe sahip olmadığını, henüz bebeklik olarak tanımlayabilecek bir dönemde olduğunu belirtmiştir. Bu noktadan hareketle erken çocukluk alanında bilimsel araştırmaların nicelik ve nitelik olarak zenginleşmesi ve bilimsel araştırmaların "çocukluk dönemine” taşınması için gerekli çabaların alan dergilerinin öncülüğünde yapılması yararlı olacaktır. Zorunlu eğitim yaşı, erken çocukluk eğitiminin desteklenmesi, okul öncesi eğitim kurumlarında kalitenin arttırılması, teorik bilgilerin pratikte alana yansımaları, ebeveynlerin bilgilendirilmesi ve desteklenmesi, bebeklik dönemine ilişkin etkili uygulamalar gibi 
konularda okul öncesi eğitim alanındaki güncel değişimlerin takip edilmesi; öğretmenlerin, ailelerin ve çocukların yüksek yararına olan uygulamaların sahada da kendine yer bulmasını sağlayacaktır.

\section{KAYNAKÇA}

Ahi, B., \& Kıldan, A. O. (2013). Türkiye'de okul öncesi eğitimi alanında yapılan lisansüstü tezlerin incelenmesi (2002-2011). Mebmet Akif Ersoy Üniversitesi Eğitim Fakültesi Dergisi, (27), 23-46.

Akyüz, Y. (1996). Anaokullarının Türkiye'de kuruluş ve gelişim tarihçesi. Milli Eğitim Dergisi, 32.

Altun, D., Şendil, Ç. Ö., \& Sahin, İ. T. (2011). Investigating the national dissertation and thesis database in the field of early childhood education in Turkey. Procedia-Social and Behavioral Sciences, 12, 483-492.

Aytaçlı, B. (2012). Durum çalışmasına ayrıntılı bir bakış. Adnan Menderes Üniversitesi Eğitim Fakültesi Eğitim Bilimleri Dergisi, 3 (1), 1-9.

Ayyıldız, E., \& Albayrak, H. S. B. (2020). Türkiye'de Zorunlu Okul Öncesi Eğitim: Güçlükler ve Firsatlar. Illke Politika Notu. 15, 67.

Bağc1, B., \& İvrendi, A. (2016). Türkiye'de okul öncesi dönem matematik becerileri ve eğitimi araştırmaları: Sentez çalışması. Necatibey Eğitim Fakültesi Elektronik Fen ve Matematik Eğitimi Dergisi, 10(2), 391-424.

Bakkaloğlu, H., Yılmaz, B., Könez, N. \& Yalçın, G. (2018). Türkiye'de okul öncesi kaynaştırma konusunda yapılan araştırmalar bize neler söylüyor? Inönü Üniversitesi Eğitim Fakültesi Dergisi, 19 (1) $119-150$.

Bekman, S. (2005). Early Childhood Education in Turkey, in B. Spodek \& O. N. Saracho (eds.) International Perspectives on Research in Early Childhood Education. Greenwich: Information Age Publishing.

Bennett, J. (2008). Early childhood services in the OECD countries: Review of the literature and current policy in the early childhood field. Florence, Italy: UNICEF Innocenti Research Centre.

Bertram T and Pascal C (2016) Early Childhood Policies and Systems in Eight Countries: Findings from IEA's Early Childhood Education Study. Hamburg: Springer.

Bowen, G. A. (2009). Document analysis as a qualitative research method. Qualitative Research Journal, 9(2), 27-40.

Can, E. \& Kılıç, Ş. (2019). Okul öncesi eğitim: Temel sorunlar ve çözüm önerileri. Milli Eğitim Dergisi, 48(1), 483-519.

Can-Yaşar, M. ve Aral, N. (2011). Türkiye'de Okul Öncesinde Drama Alanında Yapılan Lisansüstü Tezlerin İncelenmesi. Mehmet Akif Ersoy Üniversitesi Eğitim Fakültesi Dergisi, 22, 75-96.

Cresswell, J. W. (2017) Araştırma deseni [Research desing]. (S. B. Demir Çev. Ed.). Ankara: Eğiten Kitap. 
Çelik, M., \& Gündoğdu, K. (2007). Türkiye'de okulöncesi eğitimin tarihsel gelişimi. Atatürk Üniversitesi Kazım Karabekir Eğitim Fakültesi Dergisi, (16), 172-190.

Çiftçi, M., \& Ersoy, M. (2019). Okulöncesi eğitimi alanındaki araştırmaların yönelimleri: Bir içerik analizi. Cumburiyet Uluslararası Eğitim Dergisi, 8(3), 862-886.

Devlet Planlama Teşkilatı. (1967). II. Beş Yıllık Kalkınma Planı (www.dpt.gov.tr).

Devlet Planlama Teşkilatı. (1972). III. Beş Yıllık Kalkınma Planı (www.dpt.gov.tr).

Doma, E.A. ve Toran, M. (2020). Erken çocukluk çalısmalarında gündem olan konuların incelenmesi: Yaşadıkça Eğitim dergisinin 30 yllı. Yaşadıkça Eğitim, 34(2),542-560.

Forster, N. S. (2006). The Analysis of Company Documentation. In J. P. Scott (Ed.), Documentary Research (pp. 83-106). Thousand Oaks, CA: SAGE.

Guba, E. G., \& Lincoln, Y. S. (1994). Competing paradigms in qualitative research. Handbook Of Qualitative Research, 2(163-194), 105.

Güdek, M. (2012). Modernleşme döneminde Osmanl'da çocuk eğitimi ve literatürü (Yayımlanmamış yüksek lisans tezi) Ankara Üniversitesi Sosyal Bilimler Enstitüsü, Ankara.

Gül, E. D. (2008). Meşrutiyet'ten günümüze okul öncesi eğitim. Çukurova Üniversitesi Sosyal Bilimler Enstitüsü Dergisi, 17(1), 269-278.

Güneş, G. (2018). Okul öncesi fen ve doğa eğitimi araştırmalarına ilişkin bir tarama çalışması: Türkiye örneği. Erken Cocukluk Çalsmaları Dergisi, 2(1), 33-67.

Kamerman, S. B. (2006). A global history of early childhood education and care. Paper commissioned for the EFA Global Monitoring Report 2007, Strong foundations: early childhood care and education. Paris: UNICEF.

Karaoğlu, H., \& Çoban, A. E. (2019). Türkiye'de okul öncesi eğitimde dil gelişimi ile ilgili yapılan lisansüstü tezlerin incelenmesi. Erz̨incan Üniversitesi Eğitim Fakültesi Dergisi, 21(1), 211-229.

Kavak, Y., Aydın, A., \& Akbaba Altun, S. (2007). Öğretmen yetiştirme ve eğitim fakülteleri (19822007). Öğretmenin üniversitede yetiștirilmesinin değerlendirilmesi. Yüksekëğretim Kurulu Yayınlar, (5).

Kaytez, N., \& Durualp, E. (2014). Türkiye'de Okul Öncesinde Oyun ile İlgili Yapılan Lisansüstü Tezlerin İncelenmesi. Uluslararası Türk Eğitim Bilimleri Dergisi, 2014(2), 110-122.

Merriam, S. B. (2013). Nitel araștırma: Desen ve uygulama için bir rehber [Qualitative research]. (S. Turan Çev.). Ankara: Nobel Akademik Yayıncılık.

Miles, M, B. \& Huberman, A. M. (1994). Qualitative data analysis: An expanded sourcebook (2. bs). Thousand Oaks, CA: Sage.

Ogelman, H. G. (2014). Türkiye'deki okul öncesi dönem sosyal beceri araştırmaları: 2000-2013 yılları arasındaki tezlerin incelenmesi. Kahramanmaraş Sütçü İmam Üniversitesi Sosyal Bilimler Dergisi, 11(2), 41-65. 
Oktay, A. (1990). Türkiye'de okul öncesi eğitim. Marmara Üniversitesi Atatürk Eğitim Fakültesi Eğitim Bilimleri Dergisi. 2(2), 151-160.

Öztürk, F. Z., Niyazi, K. A. Y. A., \& Durmaz, E. (2015). Okul öncesi öğretmenlerinin görev sürecinde yaşadıkları eğitimsel sorunlar ve çözüm önerileri. Karadeniæ. Sosyal Bilimler Dergisi, 7(03), 68-94.

Penn, H. (2011). Policy rationales for early childhood services. International Journal of Child Care and Education Policy, 5(1), 1-16.

Britto, P. R., Engle, P. L., \& Super, C. M. (2013). Early Childhood Development. Handbook of early childhood development research and its impact on global policy, 5-20.

Regan, E. M. (1976). Early Childhood Education: Some Issues and the Implications for Decision Makers. Curriculum Theory Network, 5(3), 247-255.

Sabanc1, A., Altun, M., \& Uçar Altun, S. (2018). Okul yöneticilerinin, öğretmenlerin ve velilerin görüşlerine göre ana sınıfı eğitiminde karşlaşılan sorunlar. Kuram ve Uygulamada Ĕ̈itim Yönetimi Dergisi, 24(2), 339-385.

Sel, R. (1974). Okul öncesi eğitimin 50. y1lı ve düşündürdükleri. Okul Öncesi Eğitim Dergisi, 6(7), 36.

Schwartz, J. (1997). Early childhood education: Past, present, and future. The Educational Forum, 61(4), 343-353.

Sylva, K., Melhuish, E., Sammons, P., Siraj-Blatchford, I., \& Taggart, B. (Eds.). (2010). Early childhood matters: Evidence from the effective pre-school and primary education project. Routledge.

Temizyürek, F., \& Dinçer, F. (2014). Cumburiyet dönemi eğitim taribinde önemli bir isim: Kazım Nami Duru. CTAD, 19, 173-193.

Tuzcu, G. (2019). Türkiye'de Okulöncesi Eğitimi Yaygınlaştırma Çabaları ve Maliyeti. Pamukkeale Üniversitesi Ë̆itim Fakültesi Dergisi, 47, 88-106.

Wach, E. (2013). Learning about qualitative document analysis.

Yerliyurt, N. S., \& Ersoy, M. Okul Öncesi Eğitim Programı ile İlgili Dergipark'ta Yayımlanan Makalelerin İncelenmesi: 2013-2020. OPUS Uluslararası Toplum Arastırmalar Dergisi, 17(37), 4104-4153.

Yıldırım, A., Şimşek, H. (2013). Sosyal bilimlerde nitel araștırma yöntemleri. Ankara: Seçkin Yayıncılık.

Yılmaz, M. M., Uyar, R. Ö., \& Sı̆̆ırtmaç, A. D., (2020). Okul Öncesi Fen Eğitimi Alanında Yapılan Çalışmaların Tematik İçerik Analizi: 2015-2019 Yılları Arası. Gað̧ Üniversitesi Gað̧i Eğitim Fakültesi Dergisi, 40(2), 553-589.

Zayimoğlu Öztürk, F., Kaya, N. \& Durmaz, E. (2015). Okul öncesi öğretmenlerinin görev sürecinde yaşadıkları eğitimsel sorunlar ve çözüm önerileri. Karadeniz Sosyal Bilimler Dergisi, 7(3), 68-94. 